Pamiętnik Literacki 2021, 2, s. 265-287

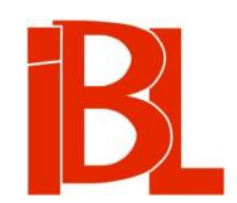

\title{
Giovanni Maver (1891-1970). Wloski promotor polskiej nauki i literatury
}

Jan Piskurewicz 
Pamiętnik Literacki CXII, 2021, z. 2, PL ISSN 0031-0514

DOI: $10.18318 / \mathrm{pl} .2021 .2 .19$

JAN PISKUREWICZ Instytut Historii Nauki PAN, Warszawa

\section{GIOVANNI MAVER (1891-1970) \\ WŁOSKI PROMOTOR POLSKIEJ NAUKI I LITERATURY}

W roku 2020 upłynęło 50 lat od śmierci Giovanniego Mavera - najwybitniejszego włoskiego polonisty, bardzo zasłużonego dla rozwoju relacji naukowych i kulturalnych między Polska a Włochami w XX wieku. Niniejsze opracowanie dotyczy jego działalności właśnie w tym zakresie.

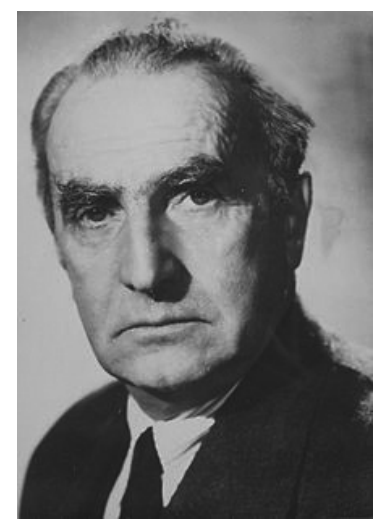

Maverowi poświęcono wiele publikacji - są to głównie teksty wspomnieniowe koncentrujące się na dorobku badacza, a także stosunkowo liczne edycje korespondencji Mavera z polskimi uczonymi. Najbardziej interesująca, najobszerniejsza i najważniejsza dla tego artykułu jest wydana w 2013 r. korespondencja z Romanem Pollakiem, pochodzaca $z$ lat $1925-1969^{1}$.

Pollak, wybitny polonista, profesor Uniwersytetu im. Adama Mickiewicza w Poznaniu, pełnił w okresie międzywojennym funkcję delegata Ministerstwa Wyznań Religijnych i Oświecenia Publicznego (MWRiOP) na Włochy. Miał on, podobnie jak

1 R. Pollak, G. Maver, Korespondencja (1925-1969). Przekł. listów Mavera z jęz. włoskiego J. Dimke-Kamola, A. Domaradzka. Wstęp, oprac. M. Rabenda. Red. nauk. B. Judkowiak. Poznań 2013 (do książki tej odsyłam dalej za pomoca skrótu K i liczb oznaczających numery stronic; na s. 18-19, 40-41 bibliografia dotyczaca Mavera). W roku 2004, wykorzystując część wydanej później korespondencji, krótki artykuł o włosko-polskich kontaktach naukowych opublikował J. S t a r n a w s k i (Włosko-polskie kontakty naukowe w świetle korespondencji Romana Pollaka 〈1886-1972〉 z Giovannim Maverem 〈1891-1970〉. W zb.: Kultura polityczna $w$ Polsce. Red. M. Ko s ma n. T. 4: Swoi i obcy, cz. 1. Poznań 2004). 
kilku innych delegatów, kierować polskimi placówkami nauki i kultury za granicą, przeważnie działającymi na zagranicznych uniwersytetach, utrzymywanymi w całości lub subwencjonowanymi przez polski rząd - zwykle były to katedry lub lektoraty polonistyki. Oprócz tego, że pracował na uniwersytecie, delegat brał też udział w organizowaniu odczytów o kulturze polskiej, opiekował się wydawnictwami, promował przekłady, wspierał pracę tłumaczy, utrzymywał kontakt z osobami interesującymi się kultura polska, współpracował z towarzystwami przyjaciół Polski, zajmował się uczonymi i stypendystami przybywającymi z Polski itp. Jednym słowem, zakres jego działań był szeroki, a zadania nieraz skomplikowane i delikatnej natury. Na przełomie lat dwudziestych i trzydziestych XX w. istniało zaledwie kilka ośrodków promocji polskiej nauki i kultury, ale liczba ich miała wzrosnąc. Pierwszą placówką był Paryż; urzędował tam Zygmunt Lubicz Zaleski. Brukselską katedrę slawistyki obją - z ramienia MWRiOP - Manfred Kridl. W Londynie wykładowcą w Slavonic and East European Studies był Julian Krzyżanowski. Katedrę w Rzymie od 1923 do 1929 r. zajmował Pollak.

W okresie międzywojennym najważniejszymi włoskimi ośrodkami upowszechniania nauki i kultury polskiej były Stacja Naukowa Polskiej Akademii Umiejętności w Rzymie, katedra jezzyka i literatury polskiej na Uniwersytecie Rzymskim oraz Istituto di Cultura Polacca „Attilio Begey” w Turynie.

Stacja Naukowa PAU (zwana też Biblioteca Polacca di Roma) powstała dzięki ofiarowaniu własnej biblioteki przez hrabiego Józefa Michałowskiego (1870-1956), ówczesnego sekretarza Poselstwa RP w Rzymie. Michałowski, pochodzacy z rodziny ziemiańskiej, studiował prawo, ekonomię i historię w Heidelbergu, Oksfordzie i Paryżu. Słuchał wykładów Alberta Sorela o rewolucji francuskiej, które wywarły wpływ na jego późniejszy wrogi stosunek do faszyzmu, dyktatury i nacjonalizmu. Swój ksiegozbiór Michałowski podarował już w r. 1921, ale oficjalną data powstania Stacji jest r. 1927, kiedy uzyskała ona siedzibę i stała się w ten sposób jedną z licznych instytucji zagranicznych - akademii i instytutów - znajdujących w Rzymie ${ }^{2}$.

W roku 1923 z inicjatywy znanego filologa klasycznego Tadeusza Zielińskiego, a przy poparciu włoskiego ministra oświaty Giovanniego Gentilego ${ }^{3}$ utworzono na Uniwersytecie Rzymskim tymczasową katedrę języka i literatury polskiej, którą objął Pollak. W roku 1927 w trakcie swego pobytu w Rzymie, w związku z planowanym ożywieniem stosunków polsko-włoskich, minister spraw zagranicznych August Zaleski uzyskał od Benita Mussoliniego zgodę na przekształcenie katedry tymczasowej w stała katedrę zwyczajna języka polskiego i literatury polskiej. Był to okres zbliżenia politycznego między Włochami a Polską. Na zasadzie wzajemności miała powstać katedra italianistyki na Uniwersytecie Warszawskim, nastapiło to jednak dopiero pod koniec 1936 roku.

2 Zob. B. Biliński, Rzym - międzynarodowy ośrodek badań naukowych. Akademie i instytuty zagraniczne. „Nauka Polska” (PAN) 1964, nr 3, s. 158. - J. P i s k u r e w i c z, Józef Michałowskizałożyciel i kierownik Stacji Naukowej Polskiej Akademii Umiejętności w Rzymie (1921-1946). „Nauka Polska” (Kasa im. J. Mianowskiego) t. 7 (1998), s. 64.

3 Giovanni Gentile (1875-1944), włoski filozof i pedagog, od 1917 r. profesor Uniwersytetu Rzymskiego, w latach 1922-1924 minister oświaty i twórca reformy włoskiego szkolnictwa, założyciel i redaktor naczelny Enciclopedia Italiana, autor rozpraw o A. Towiańskim i polskiej Wielkiej Emigracji. 
Z kolei Istituto di Cultura Polacca „Attilio Begey” w Turynie rozpoczął swoja działalność w 1930 roku. Powstał z inicjatywy Pollaka i rodziny Begeyów dla uczczenia pamięci adwokata Attilia Begeya - towiańczyka i polonofila ${ }^{4}$. Prezesem instytutu zostawał $\mathrm{z}$ urzędu aktualny rektor uniwersytetu w Turynie. Instytut gromadził bibliotekę polonistyczna, prowadził kurs języka polskiego (przy wsparciu finansowym MWRiOP), a także upowszechniał wiedzę o kulturze polskiej poprzez organizowanie odczytów i kursów na Uniwersytecie Turyńskim ${ }^{5}$.

Jak już wspomniano, Pollak pracował na katedrze Uniwersytetu Rzymskiego do 1929 roku. W tym czasie skupił wokół siebie grono Włochów zainteresowanych Polską, stworzył bibliotekę przy kierowanym przez siebie seminarium, wygłaszał też wykłady i sporadyczne odczyty w wielu miastach Włoch. Nie zamierzał jednak dłużej pozostawać na rzymskiej katedrze, co wiązałoby się nawet $z$ koniecznością przyjęcia obywatelstwa włoskiego. Od połowy lat dwudziestych coraz intensywniej rozglądał się za osobą, która mogłaby go zastąpić na tym stanowisku. Jego wybór padł na Mavera.

Giovanni Maver urodził się 18 II 1891 na dalmackiej wyspie Korčula, należącej do Austro-Węgier. Jego rodzicami byli Giovanni - Włoch o słowiańskim pochodzeniu, z zawodu leśniczy - oraz Maria z Heinrichów, z pochodzenia Austriaczka. Miejsce urodzenia i pierwszych lat życia Mavera znajdowało się na pograniczu, gdzie przenikały się kultury włoska, germańska i słowiańska, co już we wczesnym dzieciństwie pozwoliło mu poznać różne języki. Po ukończeniu szkoły średniej Maver postanowił poświęcić się filologii romańskiej. Studiował na Uniwersytecie Wiedeńskim, gdzie brał udział w seminarium Wilhelma Meyera-Lübkego, międzynarodowej sławy szwajcarskiego romanisty. Studia uzupełniał we Florencji i w Paryżu. Kilka miesięcy przed wybuchem pierwszej wojny światowej rozpoczął pracę lektora języka włoskiego we Frankfurcie nad Menem. Jego zainteresowania jednak ewoluowały. Pod koniec wojny postanowił zajać się slawistyką .

Po pierwszej wojnie światowej w Europie Zachodniej wzrosło zainteresowanie Słowiańszczyzną. Wiązało się to m.in. z powstaniem niepodległych państw słowiańskich - Czechosłowacji, Jugosławii, Polski - oraz z sytuacją panującą w Rosji. W roku 1920 uznano potrzebę utworzenia pierwszej we Włoszech katedry slawistyki. Wybór padł na Padwę - ze względu na jej położenie, 700-letnią tradycję uniwersytecką oraz tradycję studiowania na tej uczelni przez Słowian. Katedrę otrzymał 29-letni Maver, który w swoim dorobku miał wtedy tylko rozprawę doktorską i kilka recenzji. Uznano jednak, że dzięki znajomości języków i kultur słowiańskich, a także dzięki doskonałemu przygotowaniu filologicznemu był on najlepszym kandydatem. Tytuł wykładu, którym w r. 1921 Maver zainaugurował włoską slawistykę, brzmiał Occidente e Oriente: fattori di progresso e di stasi nelle

4 Attilio Begey (1843-1928), włoski adwokat, wielki przyjaciel Polski i aktywny orędownik jej niepodległości w okresie zaborów i pierwszej wojny światowej. Polski konsul honorowy i kawaler orderu „Polonia Restituta”. Zob. M. S o k o ł o w s k i, Adwokat diabła. Attilio Begey. Warszawa 2012.

5 Zob. R. Pollak, Istituto di Cultura Polacca „Attilio Begey” w Turynie. „Nauka Polska” (Kasa im. J. Mianowskiego) t. 13 (1930).

6 Zob. A. Zieliński, wstęp w: G. Maver, Literatura polska i jej zwiazki z Włochami. Wybór, przekł., oprac. A. Zielińs ki. Warszawa 1988, s. 6. 
letterature slave (Zachód i Wschód: czynniki postępu i zastoju w literaturach słowiańskich) ${ }^{7}$.

W Padwie - na uniwersytecie, w kościołach i w archiwach - Maver miał okazję zetknąc się ze śladami Polaków, którzy tak licznie studiowali w tym mieście. W roku 1922 z okazji 700-lecia wszechnicy Polska Akademia Umiejętności ofiarowała Uniwersytetowi Padewskiemu tom zawierajacy artykuły polskich uczonych odnoszace się do dawnych związków polsko-padewskich. Rok później w „L’Europa Orientale” ukazał się tekst Mavera I Polacchi all'Università di Padova (Polacy na Uniwersytecie Padewskim) ${ }^{8}$.

Na uniwersytecie Maver zajął się przede wszystkim zorganizowaniem warsztatu badawczego - biblioteki - i odpowiednim wyposażeniem nowych pomieszczeń. W roku 1926 jego katedra tymczasowa (incarico) została przekształcona w stała katedrę zwyczajną. Rozwój organizacyjny katedry nie szedł jednak w parze z poprawą sytuacji materialnej Mavera, zwłaszcza w pierwszych latach jego pracy na uczelni. Pisze o tym Jan Ślaski w swoim artykule opartym na źródłach z archiwum Uniwersytetu Padewskiego. Cytuje skierowany do rektora list Mavera, skarżącego się, że po 6 miesiącach od rozpoczęcia roku akademickiego nie dostał jeszcze obiecanego wynagrodzenia:

Czekałem cierpliwie długie miesiące, ale obecnie muszę się upomnieć - żeby móc żyć i utrzymać moją rodzinę [miał już dwóch synów - J. P.] w warunkach, które nie będą dla mnie upokarzające i będą stosowne do godności mojego zawodu ${ }^{9}$.

Być może ta niepewna materialna sytuacja pomogła Pollakowi skłonić Mavera do współpracy. Oto jak Pollak wspominał początki owej współpracy i swoją rolę w jej nawiązaniu:

Profesor Maver należał do tych Włochów, których do studium polszczyzny i do polonofilstwa, mogę powiedzieć, ja przyciagnąłem. Uważam to sobie za jedną z największych zdobyczy życiowych. Będąc w Rzymie, postanowiłem wydać osobny zeszyt zbiorowy przez Włochów opracowany, poświęcony Słowackiemu. [...] Wiedząc, że profesor Maver, profesor slawistyki w Uniwersytecie Padewskim, interesuje się także sprawami polskimi, starałem się go przyciagnnać do Słowackiego. Wybrałem się do Padwy. Specjalną perswazją wytłumaczyłem mu, że w zeszycie, który będzie poświęcony Słowackiemu, nie może zabraknąc pierwszego slawisty włoskiego ${ }^{10}$.

Rezultatem „specjalnej perswazji” były eseje Mavera o Słowackim ${ }^{11}$. Od tej pory stał się on ulubionym autorem włoskiego polonisty.

7 Zob. ibidem, s. 7. Zainteresowanie Słowiańszczyzną we Włoszech po pierwszej wojnie światowej przejawiło się także w założeniu Istituto per l'Europa Orientale z siedzibą w Rzymie. Przez 22 lata swojego istnienia instytut ten prowadził systematyczną działalność wydawniczo-popularyzacyjną obejmującą historię i kulturę słowiańską. Oprócz przeglądu „L'Europa Orientale” wydawał czasopismo „Rivista di Letterature Slave” (1926-1932).

8 Zob. S. Graciotti, Giovanni Maver. W: Od Renesansu do Oświecenia. T. 1. Warszawa 1991 (wspomnienie pośmiertne wygłoszone 10 XII 1970 w Stacji Naukowej PAN w Rzymie).

9 J. Sla s ki, Giovanni Maver e gli inizi della slavistica universitaria italiana a Padova. W zb.: Studi slavistici in onore di Natalino Radovich. A cura di R. B e n a c c h i o, L. M a g a r o t t o. Padova 1996, s. 313.

10 R. Polla k, Wtoscy polonofile. Archiwum PAN w Poznaniu (APANP), P III-63, j. 197, s. 25.

11 G. M a ve r, Saggi critici su Juliusz Stowacki. Padova 1925. 
W roku 1925, po półtoramiesięcznym pobycie w Krakowie i Zakopanem, Maver udał się do Poznania i odwiedził Pollaka, który postarał się stworzyć mu odpowiednie warunki do pracy w bibliotece seminarium historii literatury polskiej uniwersytetu. To właśnie po pobycie w Poznaniu i powrocie do Padwy Maver przygotował Saggi critici su Juliusz Słowacki (Szkice krytyczne o Juliuszu Słowackim).

Publikacja ta wzbudziła duże zainteresowanie w polskim świecie naukowym. Pracę Mavera pozytywnie skomentowali Ignacy Chrzanowski i Juliusz Kleiner. Zdaniem Ireny Mamczarz, już pierwszy szkic był „rewelacyjny pod względem metody, rozszerzał w niejednym punkcie [...] wiedzę o Słowackim i o literaturze romantyzmu"12.

Jak wspomniano, Pollak nie zamierzał obejmować katedry literatury polskiej w Rzymie, a jako najlepszego kandydata do jej objęcia widział Mavera. W lutym 1926 pisał do niego:

wielka prośba, aby Pan był łaskaw sformułować swoje warunki, pod którymi mógłby się zdecydować na objęcie profesury polonistyki w Rzymie [...]. Cieszyłbym się, gdybym Pana na swoim miejscu zostawił. Ponieważ sprawa ta jest dość skomplikowana, więc zawczasu trzeba rzecz cała przygotować. Odpowiedź Pana w tej sprawie jak najrychlejsza jest więc konieczna ${ }^{13}$.

Pollak działał wielotorowo. Po pierwsze, był w stanie zapewnić Maverowi lepsze warunki finansowe, aniżeli ten miał w Padwie, a po drugie, potrafił zorganizować mu szereg przyjazdów do Polski, finansowanych przez MWRiOP, oraz stworzyć warunki do dalszego rozwoju naukowego ze szczególnym uwzględnieniem interesów polskiej nauki i kultury. Na początku września 1926 zorganizował dla Mavera i swoich czterech włoskich uczniów podróż po Polsce, która bardzo im zapadła w pamięć. We wrześniu 1928 z ramienia MWRiOP zorganizował w Zakopanem parotygodniowy wakacyjny kurs dla włoskich lektorów i studentów znających dostatecznie język polski. Wykładowcami byli znani polscy uczeni: geograf Eugeniusz Romer, historyk Jan Dąbrowski, historyk literatury Julian Krzyżanowski, muzykolog Zdzisław Jachimecki, etnolog i socjolog Jan Stanisław Bystroń, językoznawca Kazimierz Nitsch, historyk Wacław Sobieski. Relację z otwarcia i z pierwszych wykładów przygotował m.in. Juliusz Kaden-Bandrowski, który podkreślił wielkie znaczenie tego wydarzenia dla stosunków polsko-włoskich ${ }^{14}$.

Także Maver miał wystapić jako prelegent. W liście do niego, tuż przed rozpoczęciem kursu, Pollak pisał:

Co do Pańskiego udziału w kursie zakopiańskim, to liczę na to, że Pan tam będzie przez cały kurs. Skoro Pan pisze, że lekcyj [tj. wykładów] mało przygotował, to potargujemy się trochę. W każdym razie trzy lekcje tygodniowo, a więc razem dziewięć lekcji potrafi Pan jakoś obmyślić. Jeśli o romantyzmie czy preromantyzmie zbyt długo Pan nie może mówić, to prosiłbym bardzo o poświęcenie paru lekcyj Słowackiemu, interpretacji i lekturze wyjątków z jego utworów, a zwłaszcza Króla-Ducha. Byłoby to doskonałym przygotowaniem do wykładu J. G. Pawlikowskiego, który mi obiecał wykład o Królu-Duchu i Boskiej Komedii. Jeśli to Panu nie odpowiada, to proszę wybrać te rzeczy, którymi się Pan teraz w Poznaniu zajmuje. O ile Panu byłyby koniecznie potrzebne jakieś książki z semin[arium] hist[orii] lit[eratury] pols[kiej] do tych wykładów w Zakop[anem] - to proszę je zabrać ze sobą ${ }^{15}$.

I. M a m c za r z, Giovanni Maver. „Przegląd Humanistyczny” 1971, nr 2, s. 148.

R. Polla k, list do G. Mavera, z 28 II 1926. K 63.

J. Ka den-B androwski, Goście włoscy. „Głos Prawdy” 1928, nr 262, z 9 IX.

R. Polla k, list do G. Mavera, z 24 VIII 1928. K 78. 
Maver spełnił te postulaty. W sprawozdaniu opublikowanym w „Kurierze Poznańskim" Pollak z dumą informował:

prof. Maver, w niedalekiej już przyszłości prof[esor] literatury i języka polskiego w Rzymie, biorący w kursie udział czynny i jako słuchacz, i jako prelegent, miał w języku włoskim cykl starannie opracowanych wykładów o polskim romantyzmie ${ }^{16}$.

W wykładach i dyskusjach uczestniczyło 10 osób, 8 z różnych względów nie mogło przyjechać do Zakopanego. Zdaniem Pollaka, kurs zakopiański stał się zarazem pierwszym zjazdem włoskich polonistów. MWRiOP pokryło jedynie część kosztów (prelegentów i pensjonat). MSZ opłaciło przejazdy kolejowe w Polsce. Pozostałe wydatki ponieśli włoscy uczestnicy. Jak napisał Pollak - „ofiarnie i chętnie”17.

Maver został następca Pollaka na katedrze języka polskiego i literatury polskiej na Uniwersytecie Rzymskim w r. $1929^{18}$, nie zrezygnował przy tym z prowadzenia zajęć z filologii słowiańskiej. W ramach katedry najbliższymi współpracownikami pierwszego i jak dotąd jedynego we Włoszech profesora zwyczajnego jezzyka polskiego i literatury polskiej byli kolejni lektorzy: Mieczysław Piszczkowski, Mieczysław Brahmer, Maryla Falk i Władysław Floryan. Zdaniem Andrzeja Zielińskiego, pięcioletnia (1932-1937) współpraca Mavera z Brahmerem wpłynęła na rozwój włoskiej polonistyki w bardzo dużym stopniu ${ }^{19}$.

Polonistyka stała się główną dyscypliną badawczą uprawiana przez Mavera, a przyszli uczniowie mówić będą o „orientacji polonofilskiej szkoły filologii słowiańskiej" utworzonej wokół katedry Mavera ${ }^{20}$.

Od momentu objęcia przezeń katedry na Uniwersytecie Rzymskim, a nawet nieco wcześniej, Pollak zamierzał wykorzystać uczonego w akcji odczytowej, którą prowadził z dużym powodzeniem od 1923 roku. Maver już na poczatku $1928 \mathrm{r}$. wygłosił w Rzymie odczyt L'Università di Padova e la Polonia (Uniwersytet Padewski i Polska), bardzo wysoko oceniony przez Pollaka w „Kurierze Poznańskim” jako ,jeden z najlepszych odczytów o Polsce przez Włocha kiedykolwiek wygłoszonych”21. W styczniu 1929 Pollak pisał do Mavera:

Mam nadzieję, że $\mathrm{z}$ końcem marca będę mógł $\mathrm{z}$ jaką konferencją wyprawić się do Florencji, Bolonii, a może i do Padwy lub Triestu - i na odwrót myślę, że Pan przyjedzie z jakim odczytem do Turynu i Rzymu. Może byśmy już teraz na ten temat coś skombinowali. Ja bym się postarał, żeby Pana zaprosiło na odczyt odnoszący się do kultury polskiej Towarzystwo Italia e Polonia. Proszę mi napisać, ile by wyniosły koszta takiej ekspedycji. Co do mojego zaś odczytu - to tutaj o stronę finansową nie trzeba się kłopotać. Ja na to dostanę osobno. Chodziłoby mi tylko o termin i miejsce. Gdzie potrzebniejszy byłby odczyt: w Trieście czy Wenecji, czy Padwie? Temat trochę polityczny - w każdym razie bardzo aktualny: Sui confini orientali della Polonia [Na wschodnich granicach Polski] albo La tragedia dei confini orientali della Polonia [Dramat wschodnich granic Polski] - albo jakoś jeszcze zgrabniej. Chciałbym w tym odczycie, który zresztą już w Rzymie wygłosiłem, oświetlić w perspektywie historycznej problem „Kresów

R. P o ll a k, Włosi pod Giewontem. Kurs dla polonistów włoskich w Zakopanem. „Kurier Poznański” 1928, nr 456, z 4 X, s. 8.

Ibidem.

Jego następcą na katedrze filologii słowiańskiej w Padwie został E. Lo Gatto.

Zielińs ki, op. cit., s. 15.

Zob. ibidem, s. 14.

P. [R. Polla k], Odczyt prof. Mavera. „Kurier Poznański” 1928, nr 86, z 22 II, s. 8. 
polskich", ruskich, litewskich, białoruskich, rolę Polski w kulturze tych Kresów i nasze do nich prawa. A więc rzeczy interesujące, ogólne, a niespecjalnie literackie ${ }^{22}$.

Pollak zaczął się zwracać do Mavera także z prośbami o interwencje u władz włoskich $\mathrm{w}$ sprawach bieżących, m.in. związanych $\mathrm{z}$ wymianą stypendystów między Włochami a Polską - czyli w sprawach będących w gestii delegata MWRiOP na Włochy ${ }^{23}$. Świadczy to o tym, że Pollak znacznie szerzej widział rolę Mavera w Rzymie - nie tylko jako profesora polonistyki na uniwersytecie, ale również jako realizatora planowanej w Warszawie polityki kulturalnej i naukowej.

Potwierdzeniem tej tezy może być opublikowany w 1930 r. w „Przeglądzie Współczesnym" (a zainspirowany i pewnie przetłumaczony przez Pollaka) artykuł Mavera Włosko-polskie stosunki kulturalne, w którym wskazuje on na uwarunkowania i podstawowe priorytety tych stosunków ${ }^{24}$.

Na wstępie Maver zauważa, że rozwojowi włosko-polskich kontaktów kulturalnych sprzyjają brak konfliktów politycznych w długiej historii obu nacji oraz tradycja związków kulturowych sięgających średniowiecza. Maver jest przeciwnikiem wszelkiego pośrednictwa, czerpania informacji z drugiej ręki. Opowiada się za bezpośrednim poznawaniem ludzi i kultury obu narodów. W tym celu proponuje „skłonienie Polaków i Włochów do nauczenia się języka i poznania kraju drugiego narodu" (W 92). Jeśli chodzi o praktyczne podejście do owych wskazań, postuluje przede wszystkim organizowanie wyjazdów zbiorowych, zwłaszcza młodzieży - „po dobrym przygotowaniu" - grup studentów i uczniów wyższych klas szkoły średniej. Miało to sprzyjać ich późniejszemu zainteresowaniu związkami kulturalnymi obu nacji. W tym kontekście Maver opowiada się za wzajemnym ustanowieniem stypendiów na dłuższe pobyty naukowe oraz kursów - takich jak ten zorganizowany w 1928 r. przez Pollaka w Zakopanem (W 94).

Podstawowa kwestię stanowiła oczywiście znajomość języka. Maver był zwolennikiem organizowania włoskich lektoratów na wszystkich polskich uniwersytetach, a także w wybranych szkołach średnich. Zdawał sobie sprawę, że we Włoszech język polski nie będzie cieszył się taką popularnością jak włoski w Polsce. Lektorat języka polskiego istniał jedynie na uniwersytetach w Rzymie i w Turynie (w $1931 \mathrm{r}$. utworzono również lektorat we Florencji). W Padwie uwzględniano polonistykę w ramach filologii słowiańskiej. Maver widział jednak możliwości powstania polskich lektoratów również na innych uczelniach włoskich. Najważniejszym ośrodkiem polonistycznym była katedra języka i literatury polskiej w Rzymie i istniejący przy niej lektorat. Dużą rolę w poruszaniu spraw polskich odgrywał też redagowany przez Ettorego Lo Gatta ${ }^{25}$ periodyk „Rivista di Letterature Slave” (W 96).

Istotnym czynnikiem poznania kultury innego narodu sa przekłady. Dokonał się tu pewien postęp. Przełożono takich autorów, jak Jan Kochanowski, Adam Mickiewicz, Stefan Żeromski, Władysław Stanisław Reymont czy Jan Kasprowicz.

24 G. M a ve r, Włosko-polskie stosunki kulturalne. „Przegląd Współczesny” 1930, t. 34, nr 100/101. Do artykułu tego odsyłam za pomocą skrótu W, po którym podaję numery stronic. 
Zdaniem Mavera, po literaturze rosyjskiej, w owym czasie, na pierwsze miejsce wysuwała się literatura polska (W 97).

Ponadto badacz postulował opracowanie i wydanie dobrego podręcznika historii Polski, słownika i gramatyki, a także słownika włosko-polskiego i gramatyki włoskiej. Mimo lepszej znajomości kultury włoskiej w Polsce aniżeli polskiej we Włoszech również Polacy, według Mavera, zbyt mało wiedzieli o kulturze włoskiej - może jeśli nie liczyć opery. Niewielka była znajomość filozofii i nauki włoskiej. Remedium widział Maver w publicznych odczytach i wykładach specjalistów $\mathrm{z}$ różnych dziedzin. Proponował częstą wymianę uczonych $z$ obu krajów i większe zaangażowanie dziennikarzy w upowszechnianiu informacji o kulturze Polski i Włoch (W 101).

Maver nawiązał liczne kontakty z polskimi uczonymi. Wymienić tu należy przede wszystkim znanego historyka kultury Stanisława Kota, z którym będzie on korespondował prawie do końca życia ${ }^{26}$, a ponadto polonistów, slawistów i historyków literatury, takich jak Kleiner czy Krzyżanowski. Włoski badacz korespondował też z takimi postaciami polskiej nauki, jak historyk Marceli Handelsman czy językoznawca Kazimierz Nitsch, ponadto zaś z pisarzami, m.in. z Janem Parandowskim. Już w 1930 r. został członkiem Polskiej Akademii Umiejętności. Bliskie kontakty łączyły Mavera ze znaczącymi profesorami Uniwersytetu Rzymskiego: byłym ministrem oświaty Giovannim Gentilem, dziekanem Wydziału Literackiego Nicolò Festą czy Gioacchinem Volpem ${ }^{27}$. Wzmacniały one pozycję katedry języka i literatury polskiej oraz samego Mavera.

Polityczna zgoda na powstanie katedry języka i literatury polskiej na Uniwersytecie Rzymskim nie oznaczała jednak, że Maver otrzyma jakieś świetne możliwości działania, choćby lokalowe. Jak wspominał Brahmer:

Ciasno było z początku w sędziwej rzymskiej Sapienzy - ćwiczenia w niewielkiej grupie odbywały się często w magazynie bibliotecznym (Maver był kuratorem uniwersyteckiej biblioteki), ale w nowożytnym, przestronnym „Mieście Uniwersyteckim” niebawem również slawistyka [...] uzyskała możność swobodnego oddechu ${ }^{28}$.

Przez pierwsze lata kierowania katedrą Maver w swoich wykładach i ćwiczeniach zajmował się Adamem Mickiewiczem, Stanisławem Wyspiańskim i ogólną charakterystyką kultury polskiej do końca XVI wieku. Ponadto wykładał gramatykę starosłowiańską jako wstęp do gramatyki polskiej. Średnia frekwencja nie była jednak duża. Jak podaje Brahmer, liczba studentów nie przekraczała dziesięciu, ale wśród nich pojawiały się ciekawe osobowości, np. wielostronny, przedwcześnie zmarły Luigi Salvini ${ }^{29}$ albo dobrze zaznajomiony z literatura polską Dan Danino Di Sarra ${ }^{30}$.

Zob. Korespondencja Giovanniego Mavera (1891-1970) ze Stanisławem Kotem (1885-1975). Oprac. J. Ok oń, J. Star naw ski. „Biuletyn Biblioteki Jagiellońskiej” 1998, nr 1/2.

Gioacchino V ol pe (1876-1971), profesor nauk politycznych na Uniwersytecie Rzymskim (19241940), poseł z ramienia partii faszystowskiej (1924-1929), prezes Associazione Culturale Italo-Polacca. W latach 1925-1937 kierował działem historii średniowiecznej i nowożytnej w Enciclopedia Italiana.

M. B r a h me r, Giovanni Maver (1891-1970). W: Powinowactwa polsko-włoskie. Z dziejów wzajemnych stosunków kulturalnych. Warszawa 1980, s. 311.

Luigi Salvini (1911-1957), uczeń Mavera i Brahmera, polonista i bułgarysta, badacz słowiańskich literatur ludowych.

Dan Danino Di Sarra (1913-1990), włoski slawista, pisał o polskich poetach współczesnych, 


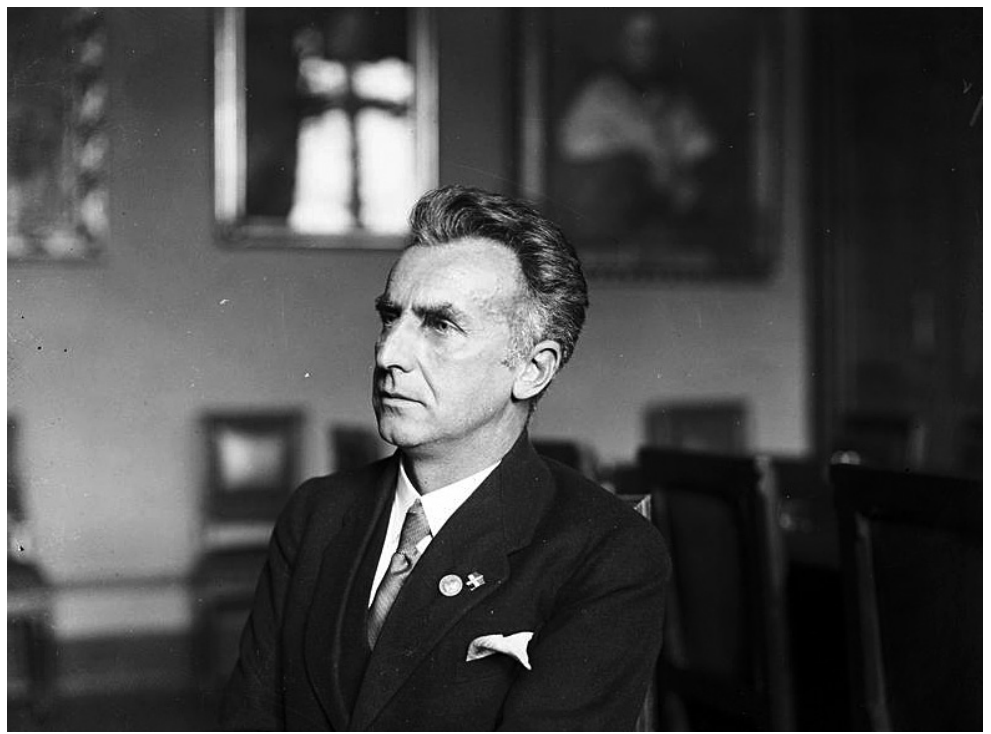

Giovanni Maver na II Międzynarodowym Zjeździe Slawistów, Kraków, 1934

Po drugiej wojnie światowej do najważniejszych uczniów Mavera należeli Riccardo Picchio, Sante Graciotti, Domenico Caccamo i Michele Colluci ${ }^{31}$. Najwybitniejszy z nich - Picchio - w latach 1947-1949 był w Warszawie lektorem języka włoskiego i prowadził wykłady z literatury włoskiej. W roku 1952 współpracował z Maverem przy zakładaniu periodyku „Ricerche Slavistiche”, którego został redaktorem po śmierci Mavera. W roku 1961 objął po Maverze katedrę w Rzymie i dyrekcję Istituto di Filologia Slava. Od roku 1967 był profesorem Yale University w USA. Ogłosił wiele prac $\mathrm{z}$ zakresu historii literatury polskiej.

Maver proponował swoich uczniów do stypendiów rządu polskiego i włoskiego, starając się w ministerstwach o zwiększenie ich liczby. Niektórzy z nich z czasem zostawali lektorami języka włoskiego na polskich uniwersytetach ${ }^{32}$.

W dniach 21-28 VIII 1933 odbył się w Polsce VII Międzynarodowy Kongres Historyków, na który z inspiracji Pollaka pojechał także Maver. W sekcji historii literatury mówił na temat literackich kontaktów Polski z Zachodem. Przy okazji, w ramach uroczystości kongresowych, na Uniwersytecie Jagiellońskim wręczono mu dyplom członka honorowego Akademickiego Towarzystwa Przyjaciół Włoch (K 109, przypis 234) ${ }^{33}$.

W roku następnym Maver uczestniczył w II Międzynarodowym Zjeździe Slawistów, obradującym w Warszawie we wrześniu 1934. Wygłosił wtedy odczyt Mickie-

m.in. o L. Staffie, K. Wierzyńskim, J. Tuwimie, brał udział w kursach wakacyjnych w Zakopanem w 1936 i 1937 roku.

31 Zob. Brahmer, op. cit.

32 G. Mave r, list do R. Pollaka, z 15 V 1931. K 95.

33 Referat Mavera nosił tytuł I contatti letterari della Polonia con le nazioni occidentali (Kontakty literackie Polski z państwami zachodnimi). 
wicz a Italia na krakowskiej części zjazdu, na posiedzeniu ku czci Mickiewicza w auli Uniwersytetu Jagiellońskiego. Wziął udział także w innych uroczystościach poświęconych Mickiewiczowi. „Kurier Powszechny” donosił:

Uczestnicy Zjazdu udali się o godzinie dwunastej na Wawel celem złożenia hołdu Adamowi Mickiewiczowi. Delegacja pod przewodnictwem prof. Rozwadowskiego, Lehr-Spławińskiego i Mavera w krypcie, gdzie spoczywają prochy Mickiewicza, złożyła na sarkofagu dwa wieńce z biało-złotymi szarfami i napisami „Collège de France - A. Mickiewicz” i „Adamowi Mickiewiczowi w hołdzie II Międzynarodowy Zjazd Slawistów". Następnie w katedrze nad kryptą świetne przemówienie wygłosił slawista włoski prof. Maver, składając hołd geniuszowi Mickiewicza jako poety, a zwłaszcza jako autora Pana Tadeusza i jako profesora Collège de France, którego wykłady nazwał bezcennym drogowskazem dla każdego slawisty ${ }^{34}$.

Najważniejszymi instytucjami organizujacymi we Włoszech odczyty o polskiej kulturze i literaturze były Stacja Naukowa PAU w Rzymie i Istituto di Cultura Polacca „Attilio Begey” w Turynie. Oprócz nich istniały efemeryczne towarzystwa przyjaźni polsko-włoskiej, które poza prelekcjami organizowały różne uroczystości, koncerty itp. Żywot tych towarzystw zazwyczaj był krótki. Zależał głównie od aktywności środowisk polskich oraz od konsulów etatowych i honorowych w danym mieście ${ }^{35}$.

Duże nadzieje wiązano ze stowarzyszeniem Associazione Culturale Italo-Polacca, powstałym w Rzymie pod oficjalnymi rządowymi auspicjami włosko-polskimi. Utworzono je z końcem 1930 r. po likwidacji krótko i anemicznie działającego towarzystwa włosko-polskiego Italia e Polonia. Prezesem nowego towarzystwa został wspomniany Gioacchino Volpe. W skład zarządu weszli także inni zaangażowani politycznie Włosi: Roberto Forges-Davanzati ${ }^{36}$ i Piero Ferretti di Castelferretti ${ }^{37}$, ponadto Włosi jakoś związani ze sprawami polskimi: Paolo Emilio Pavolini ${ }^{38}$, Ettore Lo Gatto, Giuseppe Monticone ${ }^{39}$, Polacy: Maciej Loret ${ }^{40}$, Józef Michałowski, polski konsul Karol Rościszewski, oraz sam Maver jako sekretarz zarządu i spiritus movens. Aby przyspieszyć działania stowarzyszenia Maver utworzył mały „komitet naukowy" (J. Michałowski, M. Piszczkowski, E. Damiani ${ }^{41}$, L. Salvini, G. Maver), który opracował program działalności ${ }^{42}$.

Pomimo przeszkód formalnych Maverowi udało się doprowadzić do uruchomie-

„Kurier Powszechny” 1934, nr 271, z 2 X, s. 5. Cyt. z: K 126, przypis 290.

Zob. S. Si e r p ow s ki, Stosunki polsko-włoskie w latach 1918-1940. Warszawa 1975, s. 445-446. Roberto Forge s-Davanzati (1880-1936), hrabia, członek Wielkiej Rady Faszystowskiej, założyciel i redaktor pisma „Idea Nazionale”, a po jego połączeniu $z$ „Tribuna” redaktor naczelny tego dziennika.

Piero Ferretti di Castelferretti (1896-1951), hrabia, adwokat, poseł do parlamentu włoskiego.

Paolo Emilio Pa v o li in i (1864-1942), profesor w Istituto di Studi Superiori, sanskrytolog i tłumacz literatury polskiej. R. Pollak („Anhelli” po włosku. „Przegląd Współczesny” t. 9 〈1924〉, nr 25) zrecenzował jego tłumaczenie Anhellego.

Giuseppe Montic o ne (1886-1972), ksiądz katolicki, historyk i archiwista w Congregatio de Propaganda Fide, jeden z pierwszych uczniów Pollaka w latach 1923-1924.

Maciej L o r et (1880-1949), historyk kultury i dyplomata, autor licznych prac o Polakach w Rzymie. Enrico D a mi a ni (1892-1953), uczeń Pollaka, włoski slawista, tłumacz (m.in. Trenów J. Kochanowskiego).

G. M a ver, list do R. Pollaka, z 15 V 1931. K 92-93. 
nia działalności Associazione już w 1931 roku. W maju Salvini wygłosił odczyt o polskiej pieśni ludowej, którego streszczenie ukazało się w znanym tygodniku „Italia Letteraria”, a 11 listopada nastąpiła właściwa inauguracja Associazione w Palazzo Marignoli, gdzie po oficjalnych wystapieniach Maver przedstawił referat o polsko-włoskich stosunkach kulturalnych w okresie renesansu ${ }^{43}$. Statut Associazione, sprawozdanie $z$ działalności i spis członków opublikowało czasopismo „Europa Orientale” (K 92, przypis 154).

Wspomniany „komitet naukowy” (zwany sekcją naukowa) okazał się najaktywniejszą częścią Associazione. Już od końca maja 1931 urządzał zebrania dyskusyjne, na których nawiązywał się bezpośredni kontakt między zainteresowanym Polską włoskim światem nauki a przebywającymi w Rzymie polskimi uczonymi. Associazione organizowało także odczyty na Uniwersytecie Rzymskim (m.in. Pollaka i Karoliny Lanckorońskiej ${ }^{44}$ ) oraz za pośrednictwem Mavera roztoczyło opiekę nad opracowaniem słownika włosko-polskiego przez Wandę Wyhowską de Andreis ${ }^{45}$.

W lutym 1932 Associazione w porozumieniu z Istituto Nazionale Fascista di Cultura zorganizowało cykl odczytów o Polsce współczesnej, m.in. wygłoszony

43 Referat ten wzbudził kontrowersje. Tak o całej sytuacji pisał R. Pollak w sprawozdaniu do MWRiOP (Sprawozdanie z 14-dniowego objazdu naszych placówek naukowych na terenie Włoch z końcem listopada i poczatkiem grudnia 1931. APANP, P III-63, s. 4-5): „Dnia 11 listopada odbyła się uroczysta inauguracja Tow[arzystwa] włosko-polskiego, na której prof. Maver wygłosił odczyt o stosunkach wiążących naszą kulturę z włoską w XVI wieku. Przed wyjazdem do Włoch otrzymałem streszczenie tego odczytu [...], w którym nie dopatrzyłem się żadnych jaskrawości lub jednostronności z nauką niezgodnych. Tymczasem według relacji kilku osób z kolonii polskiej, z którymi rozmawiałem [...], prof. Maver miał w swoim odczycie wyrazić się zbyt lekceważąco i ujemnie o naszej kulturze przed wiekiem XVI, jako na wpół barbarzyńskiej, która dopiero wpływ Włoch w XVI wieku z tego stanu podniósł. Nie chciałem bezwzględnie na tych relacjach polegać, zebrałem informacje inaczej nieco brzmiące w ambasadzie i z ust samego prof. Mavera. Okazało się, że prof. Maver istotnie może nieco wyjaskrawił dla kontrastu różnicę między XV a XVI wiekiem, ale opierał się w tym na źródłach polskich, cytował opinie współczesnych i w niczym prawdy historycznej ani kryteriów naukowych nie nadużył, jak się tego zresztą z góry spodziewałem. W każdym razie i prof. Maver zdawał sobie sprawę z tej sytuacji, pokazywał mi tekst swego odczytu i prosił o wyperswadowanie malkontentom, że opierał się na źródłach naukowych i że z jego strony żadnej w tym złej woli nie było. Zająłem się więc intensywnie, mimo trzech tylko dni czasu, negocjacjami i w niektórych przynajmniej osobach rankor przeciw prof. Maverowi złagodziłem. Ponieważ o jego odczycie wyrażali się również ujemnie obecni na nim, a przebywający na studiach w Rzymie historycy jacyś ze Lwowa bliżej mi nieznani, więc obu stronom proponowałem urządzić w najbliższym czasie zebranie sekcji naukowej Tow[arzystwa] włosko-polskiego, na której w drodze dyskusji można by sprawę wyjaśnić. [...] Takie postawienie sprawy dogadzało obu stronom. Dobrze się stało, że nie dopuszczono do jakichś wyjaskrawionych artykułów w naszych dziennikach. [...] Prof. Maver jest człowiekiem najlepszej woli, szczerych względem nas intencji, zbyt wysoko ceni on dobre $z$ naszym światem intelektualnym stosunki. [...] Z otrzymanego w tych dniach od p. Mavera listu widzę, że dysonans niemiły zniknął”.

44 Karolina La n ckor oń s ka (1898-2002), historyk sztuki związana z Uniwersytetem Lwowskim. Od roku 1926 przebywała w Rzymie, badając sztukę włoskiego renesansu i baroku. Była także bibliotekarką w Stacji Naukowej PAU, gdzie kierowała działem historii sztuki, który sama stworzyła. Podczas drugiej wojny światowej działała w konspiracji i była więziona przez Niemców. Po roku 1945 odznaczyła się aktywnością w Rzymie m.in. jako współzałożycielka Polskiego Instytutu Historycznego (1945) oraz Fundacji im. Lanckorońskich (1967). Od roku 1990 członkini PAU.

45 Zob. J. P i s k u r e w i c z, Ośrodki upowszechniania nauki polskiej we Włoszech 1918-1939. „Kwartalnik Historii Nauki i Techniki” 1995, nr 2, s. 65-66. 
13 lutego wykład Mavera Correnti spirituali nella Polonia del dopoguerra (Prądy duchowe w powojennej Polsce). Odczyty te odbywały się w Stacji Naukowej PAU, z której kierownikiem, Michałowskim, Maver pozostawał w dobrych stosunkach ${ }^{46}$.

W latach 1934-1935 we współpracy z polską ambasadą Maver i Michałowski zorganizowali cykl odczytów mających obejmować „całość stosunków polsko-włoskich". Subwencję z polskiego MSZ na ich przeprowadzenie uzyskał Alfred Wysocki, ambasador RP w Rzymie ${ }^{47}$. Wykład inauguracyjny, Stosunki polsko-włoskie $w$ wiekach średnich, wygłosił wybitny mediewista Jan Dąbrowski. Przybyli nań przedstawiciele włoskich władz, a także świata nauki i kultury, personel ambasady polskiej z Wysockim na czele i reprezentanci Polonii rzymskiej. Kolejne odczyty mieli inni znani polscy historycy: Stanisław Kutrzeba, Stanisław Gąsiorowski, Oskar Halecki, Marceli Handelsman i Stanisław Wędkiewicz. Gromadziły one nawet do 180 osób i znajdowały oddźwięk w polskiej i włoskiej prasie. Teksty referatów opublikowano w tomie Le relazioni fra l'Italia e la Polonia dall'età romana ai tempi nostri (Stosunki między Włochami a Polską od średniowiecza do naszych czasów), wydanym przez Istituto per l'Europa Orientale z subwencji polskiego $\mathrm{MSZ}^{48}$.

W latach 1935-1936 - ze względu na międzynarodowe sankcje w stosunku do Włoch po ich agresji na Etiopie - odczyty zostały wstrzymane. W roku 1937, po cofnięciu sankcji, prelekcje o historycznych związkach włosko-polskich wygłosili Gioacchino Volpe, Władysław Semkowicz, Stefan Komornicki i Ignacy Chrzanowski. Miały one zostać wydane $z$ subwencji polskiego MSZ także przez Istituto per l'Europa Orientale jako drugi tom Biblioteca di Roma dell'Accademia Polacca (jak nazywano Stację Naukowa PAU w Rzymie) ${ }^{49}$.

Ostatni sezon odczytów organizowanych wspólnie przez Associazione i Stację Naukową PAU to lata 1938-1939. W grudniu 1938 Maver pisał do Pollaka:

Przedwczoraj - inaugurując kolejny rok Stowarzyszenia Włosko-Polskiego - powtórzyłem odczyt o stosunku Mazziniego i jego współczesnych do Mickiewicza. Publiczność liczna. Ze strony polskiej: ambasada w komplecie. Wśród Włochów Volpe, który powiedział parę słów wprowadzenia, Pavolini, Cardinali, Guidi ${ }^{50}$ i inni wykładowcy. Niewielka grupka młodzieży ${ }^{51}$.

Zob. R. Pollak, list do G. Mavera, z 12 XII 1932. K 108.

Alfred Wys ocki (1873-1959) - dyplomata, od 1933 do 1938 ambasador Polski w Rzymie. To właśnie on wystąpił w 1937 r. z propozycją podpisania przez Polskę i Włochy konwencji kulturalnej. Zgodnie z pierwszym paragrafem projektu tej konwencji (konsultowanej w 1938 r. przez MSZ z MWRiOP) rząd polski miał zapewnić poparcie i wszelkie ułatwienia „celem rozszerzenia zakresu działalności istniejącej w Rzymie Polskiej Stacji Naukowej i przystosowania jej dla badań i rozwoju stosunków polsko-włoskich w dziale nauki, literatury i sztuki”. Paragraf drugi przewidywał udzielanie Włoskiemu Instytutowi Kultury w Warszawie i Stacji PAU w Rzymie oraz związanym z nimi instytucjom wszelkich możliwych ułatwień. Paragraf trzeci zakładał wymianę profesorów, tworzenie lektoratów, katedr historii i kultury obu zainteresowanych nacji, a także fundowanie stypendiów studenckich. Zob. Archiwum Akt Nowych, Zespół Ministerstwa Wyznań Religijnych i Oświecenia Publicznego, sygn. 281.

Zob. P i s k u r e w i c z, Ośrodki upowszechniania nauki polskiej we Włoszech 1918-1939, s. 60.

Zob. ibidem, s. 60-61.

Michelangelo G u i di (1886-1946), profesor języka arabskiego i literatury arabskiej na Uniwersytecie Rzymskim (1922-1946).

G. M aver, list do R. Pollaka, z 18 XII 1938. K 168. 
Maver miał odczyty nie tylko w Rzymie i nie tylko w ramach działalności Associazione oraz Stacji Naukowej PAU. Większość z nich była finansowana przez MWRiOP za pośrednictwem dotacji przyznawanej dla Istituto di Cultura Polacca „Attilio Begey” w Turynie. Już w 1931 r. wygłosił szereg wykładów w Turynie, Novarze, Bolonii, a następnie we Florencji.

W Turynie był to cały cykl wykładów, zatytułowany La poesia polacca dall'ultima rivoluzione alla risurrezione della Polonia (Polska poezja od ostatniej rewolucji [tj. powstania styczniowego] do odzyskania niepodległości). W pierwszych trzech wykładach uczony mówił kolejno o Asnyku i Konopnickiej, o Wyspiańskim i o Kasprowiczu.

Prelekcja w Novarze nosiła tytuł Elementi italici e caratteri indigeni della cultura polacca (O elementach włoskich i charakterze swoistym polskiej kultury). Odczyt ten, pod zmienionym tytułem Fattori principali della cultura polacca (Główne uwarunkowania kultury polskiej), Maver powtórzył w Bolonii. Drugi odczyt w Bolonii uczony wygłosił w Circolo di Cultura i odniósł - jak sam napisał - prawdziwy sukces:

Około 150-200 osób. Po odczycie od 11 do 12 w nocy odpowiadałem jeszcze na bardzo liczne pytania, które mi zadawano. Publiczność zresztą, wyjąwszy paru znajomych, była przekonana - a może nadal jest - że jestem Polakiem ${ }^{52}$.

Tak rolę bolońskich odczytów Mavera oceniał Pollak:

Przyczyniło się to w znacznej mierze do ostatecznej konsolidacji bolońskiego towarzystwa Amici della Polonia [...]. Z początkiem listopada odbyła się [jego] uroczysta inauguracja, w której wziął udział ambasador p. Przeździecki ${ }^{53}$ wraz $\mathrm{z}$ p. Romerem ${ }^{54}$. Z inauguracją połączony był koncert poświęcony muzyce polskiej. [...] Może z czasem uda się w Bolonii wskrzesić znów tradycje dawnej Akademii Mickiewiczowskiej, która tu tyle lat istniała ${ }^{55}$.

We Florencji w Istituto di Cultura włoski uczony mówił o Kochanowskim. Odczyt nosił tytuł Il primo poeta polacco (Pierwszy polski poeta) ${ }^{56}$. W roku 1931 wygłosił łącznie 6 odczytów, co - jak pisał w liście do Pollaka - „wcale nie było łatwym przedsięwzięciem" 57 .

Kilka prelekcji miał Maver w Polsce, m.in. w listopadzie 1938, gdy odwiedził Pollaka w Poznaniu, wygłosił dwa odczyty. Pierwszy, na zaproszenie poznańskiego akademickiego koła polsko-włoskiego, zatytułowany Mickiewicz nel giudizio di Mazzini e dei contemporanei (Mazzini i jego współcześni o Mickiewiczu), oraz naza-

G. M a ver, list do R. Pollaka, z 4 IV 1931. K 90. Wykład odbył się 19 III 1931.

Stefan Przeździ e cki (1879-1932), prawnik i dyplomata, od 1928 r. poseł, a od 1929 ambasador RP w Rzymie.

Tadeusz Ro m e r (1894-1971), dyplomata, radca ambasady polskiej w Rzymie w latach 1928-1932, a następnie ambasador RP w Tokio (do r. 1940) i w Kujbyszewie (1942-1943). Minister spraw zagranicznych w gabinecie Stanisława Mikołajczyka (1943-1944). Po wojnie profesor filologii romańskiej w Montrealu.

R. Polla k, Polonika włoskie w 1931 r. „Przegląd Współczesny” 1932, t. 42, nr 125, s. 401. O dziejach Akademii Adama Mickiewicza w Bolonii zob. J. P is k u r e w i c z, Z ziemi włoskiej dla Polski. Artur Wołyński i jego działalność $w$ Italii $w$ drugiej połowie XIX wieku. Warszawa 2012, s. 86-112. Zob. G. M aver, list do R. Pollaka, z 4 IV 1931. K 90.

Zob. G. M ave r, list do R. Pollaka, z 15 V 1931. K 94. 
jutrz, w tej samej małej auli uniwersyteckiej, Sztuka narracji i duch epicki w literaturze polskiej. Wykład ten opublikował po drugiej wojnie światowej jako Arte narrativa e spirito epico nella letteratura polacca w „Iridionie” (1945, nr 1/2, s. 24-34) (K 162-163, przypis 439) ${ }^{58}$. Parę dni później, 22 listopada, w siedzibie Instytutu Kultury Włoskiej w Warszawie wystapił z prelekcją Mickiewicz $w$ literaturze włoskiej i pradach umysłowych wtoskiego Risorgimenta (K 167, przypis 453) ${ }^{59}$.

Przy okazji wyjazdów do Włoch w roli delegata MWRiOP także Pollak starał się wygłaszać w różnych miastach odczyty popularyzujące polską naukę i kulturę i nawiązywać bliższe stosunki $z$ miejscową elitą intelektualną. Zawsze mógł liczyć na pomoc Mavera w tym zakresie. $\mathrm{W}$ jednym $\mathrm{z}$ listów pisał:

W porozumieniu z Romerem ustaliłem już moje itinerario, które tym razem przedstawia się może aż nadto urozmaicone, bo obejmuje kilkanaście ośrodków od Wenecji po Catanię. Niestety, brak mi na południu Włoch znajomości. Odczytami zajmą się nasi konsulowie, ale to mało. Skoro więc zostanie ustalone, kto odczyt zorganizuje, to Cię poproszę, abyś poparł mnie jako prelegenta u swoich znajomych, jakich tam będziesz miał na miejscu ${ }^{60}$.

Wybitny udział miał Maver w prezentowaniu zagadnień polskich w wielkiej Enciclopedia Italiana - jako jeden $z$ głównych jej redaktorów. Dzieło to, wydawane od 1929 r. przez Istituto Treccani, prezentujące wysoki poziom edytorski, zaplanowane na 36 tomów (po 1000 stron każdy), zawierało szeroko ujęte hasła, niekiedy prawie małe monografie, liczace po kilkaset stron druku. W początkowym okresie ze strony polskiej współpracował z wydawnictwem Maciej Loret, a także Roman Pollak - w przygotowaniu haseł działu polskiego w zakresie literatury. W latach następnych opiekę nad hasłami dotyczącymi Polski objął już całkowicie Maver, ale w stałym porozumieniu z Loretem i Pollakiem ${ }^{61}$.

W roku 1935 Enciclopedia doszła do tomu 23. Według Pollaka w żadnej innej wielkiej zachodniej encyklopedii nie było tak wiele poloniców ${ }^{62}$. Duże, kilkuarkuszowe hasło Polonia, z wieloma ilustracjami, zamieszczono w tomie 27. Poszczególne działy tego hasła opracowali poza Maverem (historia, język i literatura) m.in. Riccardo Riccardi (geografia), C. de Angelis (wojsko), A. M. Ratti (finanse), Bohdan Kieszkowski (szkolnictwo), Józef Kostrzewski (prehistoria), Jan Czekanowski (etnografia), Zdzisław Jachimecki (muzyka), Stanisław Kutrzeba (historia prawa). W tworzeniu hasła Polonia wzięło udział łącznie 9 włoskich i 6 polskich uczonych. Zdaniem Pollaka, w porównaniu $\mathrm{z}$ innymi encyklopediami zagranicznymi hasło to było najlepiej przygotowane.

Nie obyło się bez pewnych usterek formalnych i merytorycznych, ale zasadniczo zagadnienia polskie, w dużym stopniu dzięki Maverowi, zostały dobrze opracowane. Sam Maver przygotował szereg haseł dotyczacych polskich pisarzy. Jak relacjonował Brahmer, „dbał [on] o to, by, przy nieodzownej zwięzłości, nie ograniczać się

Odczyty odbyły się 16 i 17 XI 1938. Wizytę Mavera w Poznaniu opisał R. Pollak w artykule Rzymski polonista w Poznaniu („Dziennik Poznański” 1938, nr 262, z 16 XI, s. 7).

59 Sprawozdanie z tego wydarzenia ukazało się w „Myśli Narodowej” (1938, nr 52, z 4 XII, s. 807).

60 R. Polla k, list do G. Mavera, z 7 II 1933. K 112. Zob. też R. Polla k, list do G. Mavera, z 14 II 1939. K 169.

61 Zob. Pi s k u r e w i c z, Ośrodki upowszechniania nauki polskiej we Włoszech 1918-1939, s. 66.

62 R. Polla k, Polonica włoskie. „Przegląd Współczesny” t. 56 (1936), nr 166, s. 130. 
do przekazywania utartych sądów, ale - jak zawsze - dawał wyraz własnej ocenie dzieł i ich autorów"63.

W Sprawozdaniu z objazdu włoskich placówek Ministerstwa WRiOP $w$ czasie od końca lutego do końca marca 1938 r. Pollak podkreślał znaczenie Mavera w promowaniu polskiej nauki i kultury na terenie Włoch. Maver wziął wtedy udział m.in. w uroczystości ofiarowania Uniwersytetowi Padewskiemu przez Polskę popiersia Jana Zamoyskiego dłuta Antoniego Madeyskiego. Wygłosił wówczas odczyt o Zamoyskim. Przytoczmy opinię Pollaka:

Tegoroczne odczyty prof. Mavera w Turynie, Mediolanie, Wenecji, wygłoszone z ramienia Instlytutu] Begeya, dowodzą, że zainteresowania prof. Mavera w zakresie wiedzy o Polsce i jej kulturze rozszerzyły się w sposób bardzo pożądany na kulturę polskiego średniowiecza i na dziedzinę historii kultury społeczno-politycznej ${ }^{64}$.

Zdaniem Pollaka, w dalszym ciagu istniała bardzo dobra współpraca między Maverem a polską ambasadą. Pollak spotkał się dwukrotnie $z$ ówczesnym ambasadorem, Bolesławem Wieniawą-Długoszowskim ${ }^{65}$, w celu omówienia dalszych perspektyw tej współpracy.

Z tych obu bardzo pożytecznych rozmów odniosłem wrażenie, że nasz nowy ambasador wcale już dobrze orientuje się $\mathrm{w}$ interesujących nas zagadnieniach, że $\mathrm{w}$ całej pełni docenia wartość naszych placówek, że wysoko ceni walory prof. Mavera. Nie wątpię też, że i teraz współpraca $z$ ambasadą ułoży się bardzo harmonijnie ${ }^{66}$.

Pollak został zaproszony do ambasady, gdzie ambasador wręczył Maverowi złoty laur Polskiej Akademii Literatury. W sprawozdaniu napisał, że po przemówieniu ambasadora Maver „odpowiedział niezwykle sympatycznie i pięknie po polsku, podkreślając, że im lepiej poznaje naszą kulturę i Polaków, tym serdeczniej i głębiej do nas się przywiązuje" 67 .

Niestety, ówczesne wydarzenia polityczne przestały sprzyjać dalszemu rozwojowi kontaktów polsko-włoskich. Maver zdawał sobie $z$ tego sprawę i ciagle miał nadzieję na przełamanie impasu. W liście do Pollaka z lipca 1939 wyznawał:

Sytuacja międzynarodowa, która tak fatalnie sytuuje nas w przeciwnych obozach, niezmiernie mnie martwi - nie mam słów, by opisać, jak nad tym boleję. Ale nie chcę tracić nadziei: prawdziwa, głęboka sympatia, jaką w Polsce cieszą się Włochy, a we Włoszech Polska, nie może w końcu nie zatriumfować68.

W okresie wojny Maver łączył pracę w uniwersytecie z obowiązkami dyrektora

Brahmer, op. cit., s. 312.

R. Polla k, Sprawozdanie z objazdu włoskich placówek Ministerstwa WRiOP $w$ czasie od końca lutego do końca marca 1938 r. APANP, P III-63, s. 8.

Bolesław Wieniawa-D u g oszowski (1881-1942), generał, bliski współpracownik J. Piłsudskiego, 1938-1940 ambasador RP w Rzymie, we wrześniu 1939 wyznaczony na prezydenta RP nie objął urzędu na skutek sprzeciwu Francji. W okresie międzywojennym bardzo popularny w kregach artystycznych i literackich.

R. Polla k, Sprawozdanie z objazdu włoskich placówek MWRiOP wczesną wiosna 1939 r. APANP, P III-63, s. 12-13.

Ibidem, s. 13.

G. M a ve r, list do R. Pollaka, z 15 VII 1939. K 172. 
instytutów kultury włoskiej w Belgradzie i Bratysławie ${ }^{69}$. W liście do Pollaka z września 1945 pisał:

Jeśli chodzi o mnie, mogę uważać się za szczęśliwego. Bałem się, ze względu na katedrę, którą kierowałem (a która, z wyjątkiem lat 1943-1944, kiedy uniwersytet był praktycznie zamknięty, działała przez cały czas, i to z dość dobrym skutkiem w postaci licznych magisteriów), ale nikt mnie w sposób bezpośredni nie nękał ${ }^{70}$.

Maver w tych chudych latach dorabiał także jako tłumacz z różnych języków słowiańskich ${ }^{71}$. Przez całą wojnę starał się utrzymywać kontakt z polskimi przyjaciółmi.

Zdaniem Zielińskiego, Maver w 1941 r. dwukrotnie brał udział w literackich spotkaniach w rzymskiej Stacji Naukowej PAU, gdzie w gronie polsko-włoskim dyskutowano o Królu-Duchu Słowackiego. Razem z Lo Gattem i Damianim przychodził na tradycyjne spotkania świąteczne, a jesienią 1944 uczestniczył w kilku rozmowach na temat wznowienia działalności Stacji. Dyskutowano wtedy np. o nowych formach współpracy międzynarodowej i zastanawiano się nad możliwością przygotowania słownika włosko-polskiego, nad którym właśnie Maver miał sprawować ogólną opiekę ${ }^{72}$.

Wiktor Weintraub pisze, że kiedy wojska sprzymierzone zajęły Rzym, „naturalną koleją rzeczy" dom Mavera na Awentynie stał się punktem zbornym żołnierzy polskich z II Korpusu. Pozostały po tych kontaktach artykuły Mavera Mickiewicz i Włochy (w „Orle Białym”) oraz Arte narrativa e spirito epico della letteratura polacca (Sztuka narracji i duch epicki literatury polskiej) (we włoskim periodyku II Korpusu „Irydion”), a przede wszystkim mała antologia Podróże pisarzy polskich do Włoch (1946), wydana przez Oddział Kultury i Prasy II Korpusu ${ }^{73}$.

W pierwszej połowie 1947 r. zorganizowano przyjazd do Polski 20-osobowej „misji rządu włoskiego dla wznowienia stosunków kulturalnych z Polską". Na jej czele stanął Maver, co dobitnie świadczyło o uznaniu jego głównej roli w dotychczasowych kontaktach włosko-polskich. W liście do Pollaka pisał:

Jak zapewne wiesz, grupa włoskich naukowców reprezentujących najróżniejsze dziedziny nauki, dzięki uprzejmemu zaproszeniu polskiego rządu (inicjatywa naturalnie wyszła od Kota), przygotowuje się do odwiedzenia Was w Polsce, by odnowić dawne więzy i ożywić nigdy niewygasłą przyjaźń między Włochami i Polską ${ }^{74}$.

Maver był przewodnikiem całej grupy po dobrze sobie znanych uczelniach

Maver kierował tymi instytutami w czasie wojny, a nie, jak podaje Zieliński (op. cit., s. 18), „w pierwszych latach powojennych”.

G. Mave r, list do R. Pollaka, z 7 IX 1945. K 183.

G. M aver, list do R. Pollaka, z 15 X 1945. K 184.

Zieliński, op. cit., s. 17-18.

W. We in tra ub, Giovanni Maver (1891-1970). W: O współczesnych i o sobie. Wspomnienia, sylwetki, szkice literackie. Oprac., wstęp S. B a ra ń c za k. Kraków 1994, s. 443. Można dodać, że w „Orle Białym” (1944, nr 34 〈124〉) G. Maver opublikował jeszcze artykuł Niezapomniane przedstawienie - o Ślubach panieńskich, wystawionych w r. 1926 (przeł. H. W a ga). Ponadto ukazały się tam teksty E. D a mi a ni e go O kulturze włoskiej $w$ Warszawie i E. Lo Gatta Włoscy artyści $w$ Warszawie (oba w tym samym tłumaczeniu).

G. M a ver, list do R. Pollaka, z 10 V 1947. K 196. 
i środowiskach kulturalnych w Polsce. Konieczność stałego kierowania ta misja sprawiła, że nie mógł przyjechać do Poznania, aby odwiedzić Pollaka, który w związku z tym sam udał się do Warszawy, gdzie spotkał swego przyjaciela po raz pierwszy od $1939 \mathrm{roku}^{75}$.

Po wojnie slawistyka, w tym i polonistyka, przeżywała we Włoszech poważne załamanie. W liście do Pollaka $z$ kwietnia 1949 Maver tak przedstawiał ów kryzys i jego przyczyny:

Zainteresowanie kierunkami slawistycznymi znacznie zmalało w ciągu ostatnich dwóch lat. W tym roku na zajęcia z polskiego przychodził do mnie tylko jeden student. Stoją za tym prawdopodobnie dwie przyczyny: ogólny kryzys studiów filologiczno-humanistycznych oraz brak możliwości wyjazdu po zamknięciu instytutów kultury włoskiej w krajach słowiańskich [...] i po wstrzymaniu wymiany stypendialnej. Główną winę za ten stan rzeczy ponosi niewątpliwie krótkowzroczny rząd włoski. Czy i jak można zapobiec groźbie całkowitego oddalenia się kulturalnego naszych państw - nie potrafię powiedziećc $^{76}$.

Od roku 1953 Maver redagował założone przez siebie pismo poświęcone literaturom słowiańskim - „Ricerche Slavistiche”77. Dzięki swemu poziomowi zajęło ono czołowe miejsce wśród europejskich periodyków slawistycznych. Zdaniem Zielińskiego, „kojarząc zamysł syntetyczny z szacunkiem dla wartościowych przyczynków, stało się ono niemal emblematem "szkoły Mavera", zyskując współpracę uczonych z różnych ośrodków i krajów"78. Maver starał się tam możliwie szeroko uwzględniać problematykę polską. W liście do Pollaka z grudnia tegoż roku zapewniał, że „czyni i będzie czynił wszystko, co możliwe, by w każdym numerze Polska była obecna"79.

W roku 1955 przypadała setna rocznica urodzin Mickiewicza, w Polsce bardzo uroczyście obchodzona. Wydarzenia rocznicowe organizowano również za granicą. Maver, inspirowany przez Pollaka, pragnął wpisać się w te obchody. Pollak sugerował m.in., żeby cały numer „Ricerche Slavistiche” poświęcić Mickiewiczowi, to jednak - zdaniem Mavera - nie było możliwe. Grono potencjalnych, kompetentnych włoskich autorów nie było bowiem na tyle liczne, ażeby mogło wypełnić wartościowymi artykułami cały zeszyt czasopisma. Niemniej uczony zapewniał, że Mickiewicz znajdzie w „Ricerche Slavistiche” właściwe upamiętnienie ${ }^{80}$.

W tymże roku doszło do nawiązania kontaktów między polskim a włoskim komitetem obchodów mickiewiczowskich. We włoskim główną rolę odgrywał oczywiście Maver. Projektował sesję mickiewiczowska w Rzymie z udziałem polskich i włoskich uczonych, antologie przekładów Mickiewicza, osobne wydanie przekładu

G. Mave r, list do R. Pollaka, z 19 VI 1947. K 198.

G. M a ve r, list do R. Pollaka, z 13 IV 1949. K 209.

Pierwszy tom (za r. 1952) ukazał się jako publikacja dwóch instytutów Uniwersytetu Rzymskiego: filologii słowiańskiej i wschodnioeuropejskiego, oraz Seminario di Slavistica dell'Istituto Universitario Orientale w Neapolu. W skład komitetu redakcyjnego, oprócz Mavera jako redaktora naczelnego, wchodzili E. Damiani, E. Lo Gatto i L. Pacini. Po śmierci Damianiego w 1953 r. do komitetu dołączył R. Picchio jako sekretarz.

Zielińs ki, op. cit., s. 19.

G. M a ve r, list do R. Pollaka, z 26 XII 1953. K 215, 223. Już w pierwszym tomie „Ricerche” włoski uczony zrecenzował dwa polonika: Mickiewicz interpretato da Juliusz Kleiner oraz publikację M. i M. B e r s a n o - B e g e y ó w La Polonia in Italia. Saggio bibliografico 1799-1948 (Torino 1949). G. Mave r, listy do R. Pollaka, z 24 III 1954 (K 226) i z 20 XII 1954 (K 241-243). 
Sonetów krymskich i innych liryków. Zamierzano także wybić medal okolicznościowy i reprodukować go na kartkach pocztowych. Ponadto postanowiono zorganizować „oficjalne” konferencje naukowe w Bolonii, Mediolanie, Florencji i Turynie. Ich serię miała zamknąć uroczysta sesja na Kapitolu. Chciano też ufundować nagrody za najlepszy artykuł o Mickiewiczu w prasie codziennej i periodycznej oraz za najlepszą rozprawę pogłębiającą wiedzę o Mickiewiczu. Pisał Maver do Pollaka: „Nie wszystko to uda się w pełni zrealizować, najważniejsze jednak, że Włochy nie zawiodą i w setną rocznice godnie uczczą Mickiewicza" 81 .

Ze zrealizowanych projektów wymienić należy przede wszystkim zredagowaną przez Mavera antologię mickiewiczowską Pagine scelte (Milano 1956), przetłumaczony i zredagowany przez Carla Verdianiego tomik poezji Mickiewicza Liriche e sonetti amorosi (Milano 1956), wybicie medalu pamiątkowego oraz uroczysta sesję na Kapitolu ${ }^{82}$.

Sesja odbyła się 26 XI 1955 i stanowiła inaugurację Roku Mickiewiczowskiego we Włoszech. Główny referat, Mickiewicz vivo (Mickiewicz żywy), wygłosił Pollak, któremu, mimo utrudnień ze strony polskich władz, udało się przybyć do Rzymu na $\operatorname{czas}^{83}$.

Z kolei w dniach 17-20 IV 1956 Polska Akademia Nauk zorganizowała w Warszawie międzynarodową sesję naukową Adam Mickiewicz 1855-1955, na którą przybyła liczna delegacja włoska, $z$ Maverem na czele. Wygłosił on wtedy referat Mickiewicz i Mazzini, który wywołał żywą dyskusję. Głos w niej zabierali Henryk Bartkowski i Adam Lewak. Włoski uczony wziął też udział w dyskusji nad referatem Josipa Hamma Adam Mickiewicz i Medo Pucić ${ }^{84}$. Przy okazji odwiedził Pollaka w Poznaniu i 25 kwietnia wygłosił w Poznańskim Towarzystwie Przyjaciół Nauk referat - także o Mickiewiczu i Mazzinim ${ }^{85}$.

81 G. Maver, list do R. Pollaka, z 8 VI 1955. K 255-256.

82 Zob. ibidem. K 255.

83 Na temat tego wyjazdu zob. listy R. Polla ka do G. Mavera z 15 XI, 23 XI i 25 XII 1955 (K 260 264).

84 Zob. Adam Mickiewicz 1855-1955. Międzynarodowa sesja naukowa Polskiej Akademii Nauk, 17-20 kwietnia 1956. Red. K. Wyka, J. Rużyło-Pawłowska. Wrocław 1958, s. 212-225, 247, 363-364.

85 G. Maver, list do R. Pollaka, z 29 III 1956. K 271. Oto jak swoje wrażenia z pobytu w Polsce opisał G. Maver w liście do S. Kota z 25 VI 1956 (w: Korespondencja Giovanniego Mavera $\langle 1891-1970\rangle$ ze Stanisławem Kotem 〈1885-1975〉, s. 128-129): „Sytuację [...] można pokrótce podsumować tak: życie w Polsce jest raczej ciężkie i trudne (przede wszystkim $z$ racji o charakterze ekonomicznym: sklepy są źle zaopatrzone, często nie ma w nich rzeczy najprostszych [...], ale nie można mówić o nędzy). Obserwowałem uważnie ludzi na ulicach i mogłem skonstatować, że dzieci są dobrze odżywione i zadbane [...], że młodzież od 15 do 30 lat ma przeważnie wygląd nieco oklapnięty [...], że ludzie starzy, choć opłakując dawne czasy, robią co tylko możliwe (z godnym podziwu uporem), aby przystosować się do trudnych czasów dzisiejszych. Nastrój jest w sumie mniej przygnebiający, niż się to wydaje za granicą. To, czego w gruncie rzeczy pragną mniej lub bardziej wszyscy, to [...] trochę wolności [...] i poprawy warunków ekonomicznych. Chodzi nie tylko o "wolność od strachu", lecz o wolność od ingerencji systemu w życie codzienne [...]. Możliwość wyjazdu za granicę stanowi wciąż miraż, który niewielu może zrealizować, ale także z tego punktu widzenia perspektywy bardzo się polepszyły w stosunku do tego, co było. Inną wielką trudność stanowi ciasnota mieszkań. Większość kolegów żyje z rodzinami jedynie w dwóch pokojach. W "studiach" kolegów prawie zawsze znajdowałem łóżko obok biurka. [...] Sympatyczne jest ogromne 
Kolejną okazją do przyjazdu Mavera do Polski była konferencja naukowa zwana Zjazdem Słowackiego, zorganizowana 25-28 XI 1959 w Warszawie w związku ze 150 rocznicą urodzin poety ${ }^{86}$. Maver, słusznie uważany za najlepszego znawcę Słowackiego nie tylko we Włoszech, nie mógł przybyć ze względu na stan zdrowia. Pollak, przesyłając mu relację $\mathrm{z}$ tej konferencji, pisał:

Więc już minęły dni Zjazdu Słowackiego, którego defektem jednym z najdotkliwszych była Twoja nieobecność. Dałem temu wyraz publicznie, zabierając głos [...] i wyrażając żal, że w Zjeździe niestety nie uczestniczy najlepszy na Zachodzie znawca Słowackiego. Wspomniałem o Twoich pracach dawniejszych i ostatnich o Słowackim, wspomniałem o tych pięknych kartach, które mu poświęciłeś w Letteratura polacca, i o zamierzonym szkicu o drobnych wierszach Słowackiego. Zakończyłem wyrażeniem $\mathrm{Ci}$ w imieniu uczestników Zjazdu serdecznych pozdrowień i zredagowałem odpowiedni tekst telegramu, który zapewne otrzymałeś. Audytorium przyjęło to moje przemówienie z gorącym aplauzem i aprobatą ogólnąi 87 .

Maver przygotował na rocznicę Słowackiego referat Il messaggio poetico di Juliusz Słowacki (Przesłanie poetyckie Juliusza Słowackiego) ${ }^{88}$. Uroczystości związane ze Słowackim we Włoszech organizował przede wszystkim Bronisław Biliński, dyrektor Stacji Naukowej PAN w Rzymie ${ }^{89}$, z którym Maver zgodnie współpracował, podobnie jak to miało miejsce przed wojną w odniesieniu do Michałowskiego - ówczesnego dyrektora Stacji Naukowej PAU. Na prośbę Bilińskiego włoski uczony wygłosił wspomniany referat na uroczystości odsłonięcia płyty pamiątkowej poświęconej Słowackiemu. W liście do Pollaka pisał:

Moje słowa, wypowiedziane z sympatią, jaką żywię dla Słowackiego, którą Ty dobrze znasz, wydaje się, że spodobały się licznej i doborowej publiczności (wraz z dyrektorem Monteverdim było tam trzech profesorów z mojego Wydziału) ${ }^{90}$.

Swoje odczyty i wykłady na temat polskiej literatury Maver prezentował nie tylko we Włoszech i w Polsce - m.in. w 1953 r. na zaproszenie Instytut d'Études Slaves wygłosił w Paryżu dwa referaty: La vie rurale dans la littérature polonaise (Życie na wsi w literaturze polskiej) oraz „Les rythmes” de M. Sęp Szarzyński („Rytmy” M. Sępa Szarzyńskiego), a w 1958 r. w Berlinie pierwszą wersję referatu Il messaggio poetico di Juliusz Słowacki (Przesłanie poetyckie Juliusza Słowackiego) ${ }^{91}$.

Traumatyczne wydarzenia rodzinne (śmierć żony i syna), jak również te zwią-

zapotrzebowanie na kulturę [...]. Sytuacja profesorów (z wyjątkiem uprzywilejowanych) jest nie do pozazdroszczenia, ale nie jest też i nieznośna. Wielu z naszych przyjaciół zachowało tytuły i pobory, ale nie sądzę - jako że otwarcie "anty" - żeby i wykłady. Mają za to inne powinności (słowniki, wydania itd.), które pozwalają im kontynuować własną aktywność [...]".

Zob. A. W it kow s ka, Sesja naukowa ku czci Juliusza Stowackiego, 25-28 listopada 1959. „Pamiętnik Literacki” 1960, z. 2.

87 R. Polla k, list do G. Mavera, z 1 XII 1959. K 344.

88 G. M a ve r, Il messaggio poetico di Juliusz Stowacki. W zb.: Juliusz Stowacki. Nel $150^{\circ}$ anniversario della nascita. A cura di G. Maver, M. Żmigrodzka, B. Meriggi, B. Biliński. Roma 1961.

89 Bronisław Bilińs ki (1913-1996), filolog klasyczny, od 1951 r. profesor uniwersytetu we Wrocławiu, od 1954 Uniwersytetu Warszawskiego. W latach 1957-1983 dyrektor Stacji Naukowej PAN w Rzymie.

90 G. M aver, list do R. Pollaka, z 6 XII 1959. K 347.

91 G. M aver, listy do R. Pollaka, z 1 II 1953 (K 215-216) i z 29 I 1958 (K 305). 
zane $z$ wojną, $z$ pewnością odbiły się na zdrowiu Mavera. Po wojnie często chorował, cierpiał na rozstrój nerwowy i depresję. Wpływało to na jego możliwości twórcze. Czasem nawet nie był w stanie pracować. W roku 1959 na propozycję Pollaka, żeby rozwinać swój artykuł o literaturze polskiej zamieszczony w zbiorze prac o literaturach europejskich i amerykańskich ${ }^{92}$, odpowiedział:

Trudność [...] pojawia się jedynie z mojej strony. A ja, niestety, do kiedy mój stan zdrowia się nie poprawi, nie mogę podjąc się żadnego zadania (nawet napisania artykułu czy referatu). Naturalnie nie tracę nadziei, że znów będę mógł pracować, choćby w ograniczonym zakresie, ale skąd mieć pewność?93

Pewności nie było, ale jednak zdarzały się jeszcze okresy, gdy Maver mógł wydajnie działać naukowo. Sprzyjała temu zmiana miejsca pobytu. W lutym 1962 włoski uczony pisał do Pollaka:

Myślę, że schronię się ponownie w Paryżu za około dziesięć dni, ponieważ, ku mojemu wielkiemu zdziwieniu, przekonałem się, że wszystkie moje kłopoty nerwowe pochodzą ze wzburzenia, którego w Rzymie dostarcza mi nawet niewinna rozmowa telefoniczna. W Paryżu natomiast pracowałem z młodzieńczą bystrością, przerywając prace podczas dnia jedynie na czas niezbędny do skonsumowania skromnego i szybkiego obiadu. [...] W rezultacie tego radosnego wysiłku w Paryżu zrobiłem przez trochę ponad miesiąc więcej, niż byłem w stanie zdziałać przez rok lub dwa w Rzymie. [...] O mnie mogę $\mathrm{Ci}$ powiedzieć, że jeszcze do niedawna czułem się godny śmietnika, do którego wyrzuca się makulaturę. Lecz teraz, po „kuracji” paryskiej, znów jestem „w formie” i mam nadzieję, że doprowadzę do końca kilka co bardziej absorbujących prac. Serce, nerwy i żołądek nie dostarczają mi już tych zmartwień co wcześniej, jedynie moja artroza, która zaostrzyła się już zeszłego roku, ostatnio pogorszyła się w Pary$\dot{z ̇ u}$, najprawdopodobniej z powodu wysokiej wilgotności. Należę już do kategorii: „Kulawi” [napisane po polsku - J. P.]... Co robić! Nie można mieć wszystkiego, gdy kończy się 70 lat (pojutrze 71) ${ }^{94}$.

W roku 1961 Maver przeszedł na emeryturę, a w rzymskim Instytucie Slawistyki nastapiły zmiany personalne. Następcą na stanowisku dyrektora został Riccardo Picchio. On też objął katedrę filologii słowiańskiej i - jako profesor kontraktowy - zajęcia z języka polskiego i literatury polskiej. W ten sposób katedra zajmowana przez Mavera przez ponad 30 lat (a przedtem przez Pollaka) uległa faktycznej likwidacji. Wprawdzie Maver pocieszał Pollaka, że „sprawy będą się [...] miały w gruncie rzeczy tak samo jak przez minione trzydzieści lat"95, ale było to jednak zamknięcie pewnej epoki i obaj uczeni zdawali sobie $z$ tego sprawę. Przyjmując do wiadomości zaistniały stan rzeczy, Pollak starał się mimo wszystko nie tracić optymizmu:

Istotnie, w obecnych warunkach nie widzę innego rozwiązania od tego, o którym piszesz. Gdyby jednak doszło do jakiejś umowy o współpracy kulturalno-naukowej między Włochami a Polską, to zapewne bez trudu można by uzyskać katedrę italianistyki w Polsce i polonistyki w Rzymie ${ }^{96}$.

Pomimo przejścia na emeryturę i małej aktywności naukowej Maver postrzegany był stale jako ambasador polskiej nauki i kultury w Rzymie, więc kiedy otrzy-

G. M a v e r, Letteratura polacca. W zb.: Storia delle letterature moderne d'Europa e d'America. Dir.

da C. Pellegrini. T. 5. Milano 1958.

G. M a ver, list do R. Pollaka, z 20 IV 1959. K 326.

G. Maver, list do R. Pollaka, z 16 II 1962. K 374, 376.

G. Maver, list do R. Pollaka, z 18 X 1961. K 359.

R. Polla k, list do G. Mavera, z 30 X 1961. K 362. 


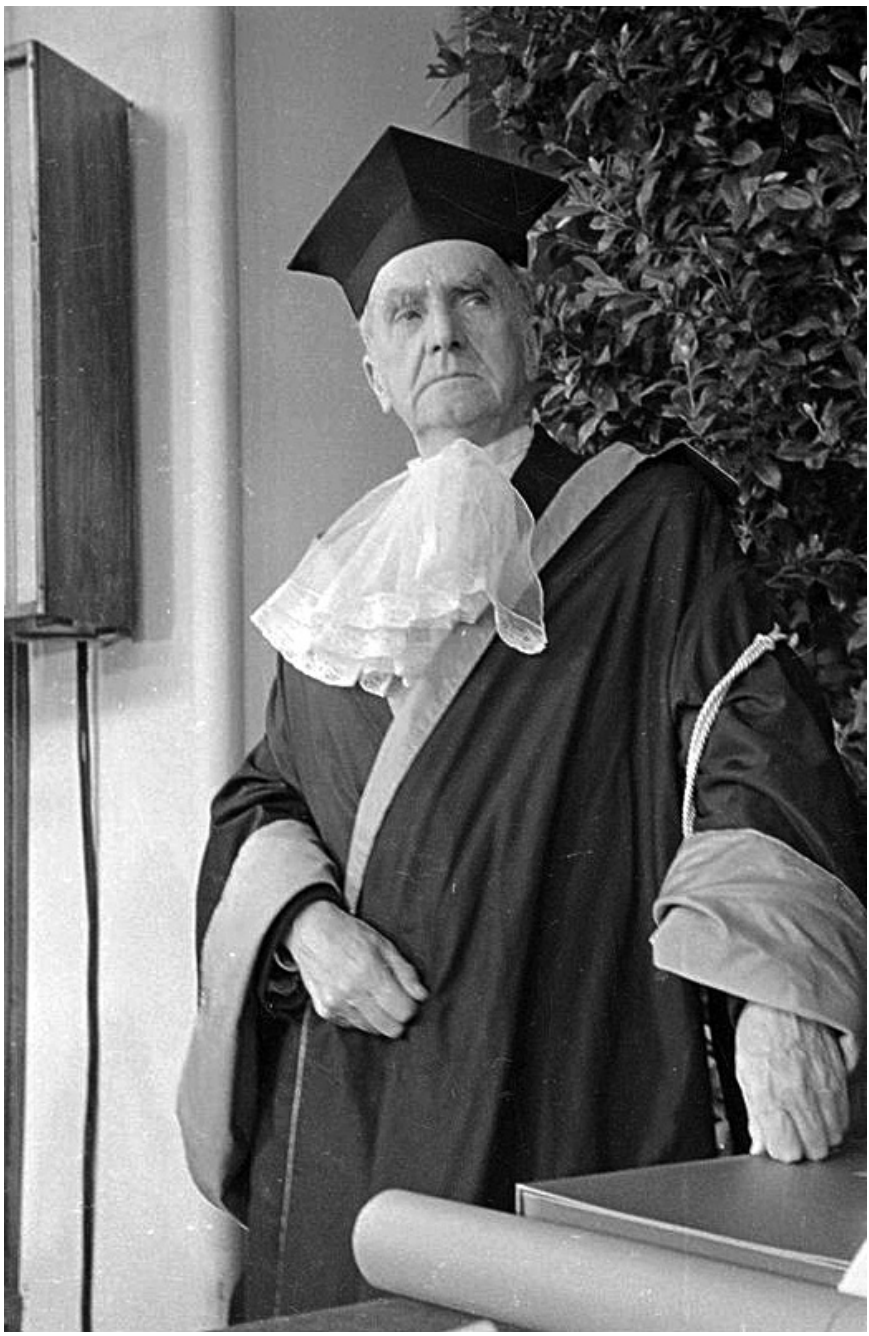

Giovanni Maver na jubileuszu 140 rocznicy założenia Uniwersytetu Warszawskiego, 14 V 1958

mano zgodę i poparcie miasta oraz władz państwowych na postawienie pomnika Mickiewicza w Villa Borghese, to właśnie do Mavera zwrócono się o wygłoszenie krótkiego przemówienia w czasie uroczystości na Kapitolu w kwietniu $1963^{97}$.

Od roku 1955 Maver przewodniczył Międzynarodowej Komisji Studiów Slawistycznych w ramach Międzynarodowego Komitetu Nauk Historycznych. W roku 1956 został wybrany na członka zagranicznego Polskiej Akademii Nauk, a w r. 1958, podczas obchodów 140-lecia Uniwersytetu Warszawskiego, otrzymał doktorat honoris causa UW. Uroczystość odbyła się 14 maja, a promotorem doktoratu był 
Brahmer. Został także Maver członkiem honorowym Towarzystwa Literackiego im. Adama Mickiewicza. W maju 1962 obchodził jubileusz pracy naukowej. Uroczystość odbyła się na Uniwersytecie Rzymskim. Jubilatowi ofiarowano księgę pamiątkową oraz zeszyt „Pamiętnika Literackiego” (1961, z. 4), dedykowany mu przez redakcję „Pamiętnika”, a wręczony przez Bronisława Bilińskiego.

Spośród stosunkowo licznych wspomnień o Maverze, w których omawiano przede wszystkim jego dorobek naukowy, chyba najbardziej merytoryczny wydaje się artykuł Picchia ${ }^{98}$. Jego spojrzenie na życie i prace Mavera różni się zasadniczo od perspektywy osób, które nie pozostawały w tak bliskim kontakcie ze swoim mistrzem. Jest zdecydowanie bardziej rzeczowe i bezpośrednie. Przytoczmy fragment:

życie Giovanniego Mavera było splotem osobistych klęsk i akademickich sukcesów. Maver umarł osamotniony i na progu ubóstwa, w pokoju o klasztornie nagich ścianach swego domu na Awentynie, po miesiącach pełnego godności i niezmąconej świadomości oczekiwania na śmierć oraz przeżywania na nowo w pamięci długiej agonii żony i tragicznej śmierci obu synów.

Dobiegał osiemdziesiątki i poprzez jego opanowane słowa wyczuwało się zdziwienie na myśl, że przeżył tyle klęsk. Dyscyplina humanistyczna wdrożyła go do patrzenia prawdzie prosto w oczy: był świadom wyjątkowej bystrości swej własnej inteligencji, wiedział również, że to, co napisał, dawało bardzo niepełny obraz jego możliwości. $Z$ latami wzmagały się opory przeciwko pisaniu, które w pewnej mierze pojawiły się jeszcze w młodym wieku jako reakcja nerwowa na nieuleczalną chorobę żony. Dawał co mógł: skondensowane artykuły zamiast książek, fragmenty badań zamiast syntez i godziny rozmów z uczniami i przyjaciółmi. W europejskim świecie uniwersyteckim wcześnie spopularyzował się obraz Mavera, pełnego polotu rozmówcy i skapego pisarza. Ten topos biograficzny, rezultat w znacznej mierze autokrytycznych wypowiedzi samego protagonisty, nie powinien zbytnio zaciążyć na jego ocenie. Jeśli jest prawdą, że po człowieku takiego kalibru intelektualnego (który sprawił, iż był jednym z wielkich mistrzów współczesnej krytyki) można było oczekiwać bardziej zobowiązujących dzieł, nie wolno równocześnie nie doceniać jego dorobku, który posiada zasadnicze znaczenie dla slawistyki naszych czasów ${ }^{99}$.

Picchio podkreśla bogactwo i rozległość dorobku Mavera, obejmującego ponad 170 publikacji. Sa tam prace interesujące zarówno dla slawistów, jak i dla romanistów. W zakresie literatury duże znaczenie dla komparatystów mają synteza Le letterature slave (1927) oraz rozprawy teoretyczne Lo studio delle traduzioni come mezzo d'indagine linguistica e letteraria (1930) i Il problema della storia comparata delle letterature slave (1938). Maver jest autorem prac dotyczących literatur południowosłowiańskich, rosyjskiej i czeskiej. Przede wszystkim był jednak wybitnym polonistą. Najwięcej uwagi poświęcił Słowackiemu, Mickiewiczowi i Kochanowskiemu - na temat ich dzieł i epok, w których żyli, napisał szereg artykułów. Swego rodzaju syntezę studiów Mavera nad literatura polską stanowi rozprawa La letteratura polacca: na około 150 stronicach zawarł w niej „ekstrakt [...] rozległych przemyśleń krytycznych”, nad którym „żaden polonista nie może przejść do porządku dziennego" ${ }^{100}$. Reasumując, Picchio stwierdza:

R. Pi c c h i o, Giovanni Maver (1891-1970) ijego szkoła. Przeł. W. W e in t r a u b. „Kultura” (Paryż) 1971, nr 7/8. Z innych wspomnień warto wymienić przede wszystkim te autorów bezpośrednio związanych z Maverem: Ma m czarz, op. cit. - R. Pollak, Giovanni Maver (18 lutego 1891 12 lipca 1970). „Pamiętnik Literacki” 1971, z. 1. - S. Graciotti, Giovanni Maver, studioso e amico della Polonia. Wrocław 1973. - B r a h m e r, op. cit.

99 Picchio, op. cit., s. 180-181.

100 Ibidem, s. 183. 
[...] Giovanni Maver był przez dziesięciolecia polonistą o najszerszych na Zachodzie kompetencjach, dzięki temu że bardziej niż „specjalista” od polskiej literatury i historii kultury był „slawistą, którego rozległość perspektyw gwarantowało solidne ogólne przygotowanie humanistyczne oraz specyficzne doświadczenie w wielkich dziedzinach filologii nowożytnej, romanistyce i germanistyce. Osiagnięcia Mavera w Rzymie przyczyniły się chyba bardziej niż studia któregokolwiek bądź z wybitnych polskich polonistów do wpisania literatury polskiej w żywy europejski kontekst krytyczny naszych czasów ${ }^{101}$.

\section{Maver zmarł w Rzymie 12 VII 1970. W nekrologu opublikowanym w „Pamięt-} niku Literackim" jego długoletni przyjaciel Pollak napisał:

Czynny udział profesora Mavera w kształtowaniu - nie tylko w samych Włoszech, ale i w Polsce wiedzy o naszym życiu literackim zasługuje w pełni na wysoką ocenę i na głęboki szacunek. Przez blisko pięćdziesiąt lat jakże niespokojnych, zwichrzonych - zawsze żywa była jego pamięć o Polsce dalekiej, a przecież tak mu wciąż bliskiej. Bo też ciążył ku niej stale nie tylko swą niepospolitą umysłowością, nie tylko przez swą sympatię żywą do kraju, do ludzi, których tu bliżej poznał, ale chyba także sercem gorącym z tą Polską się związał. Wśród nas zdobył sobie grono oddanych przyjaciół i niemało szczerych sympatyków.

W dziejach włosko-polskiej przyjaźni zapisał się na zawsze złotymi głoskami ${ }^{102}$.

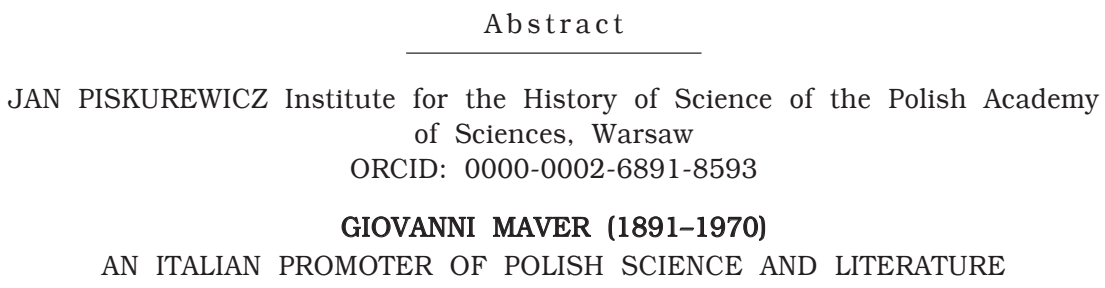

Giovanni Maver, the most outstanding Italian researcher in Polish Studies, is a meritorious figure for the development of the $20^{\text {th }}$ century Polish scientific and cultural relations with Italy. He is known first and foremost as the author of numerous studies, as a scholar, Head of the Chair for Polish Language and Literature, the University of Rome, and also as a collaborator with many Polish academic and cultural institutions in Italy and in Poland. This collaboration is made the subject of the present paper. Roman Pollak, an illustrious literary historian and Maver's long-time friend, proved to have had greatest contribution in acquiring him for the Polish Studies. The article also touches their private contacts, cooperation, and bonds that lasted until the end of Maver's life.

101 Ibidem.

102 R. Pollak, Giovanni Maver (18 lutego 1891 - 12 lipca 1970). „Pamiętnik Literacki” 1971, z.1, s. 428 . 